\title{
MODEL PEMBELAJARAN KESIAPSIAGAAN BENCANA GEMPABUMI DI SEKOLAH DASAR
}

\author{
Syahrial ${ }^{1}$ ), Kosim ${ }^{1)}$, ( Wayan Gunada ${ }^{1}$, Muhammad Zuhdi ${ }^{1)}$ \\ 1)Program Studi Pendidikan Fisika, FPMIPA, Universitas Mataram, Mataram, NTB, Indonesia \\ Corresponding author: Syahrial A \\ E-mail : syahrial_ayub@unram.ac.id
}

Diterima 15 Oktober 2019, Disetujui 14 November 2019

\begin{abstract}
ABSTRAK
Mengajar adalah pekerjaan guru sehari-hari. Namun demikian, mengajar bagaimana siswa belajar, ternyata tidaklah mudah. Penelitian ini adalah penelitian dan pengembangan (Research and Development) atau yang biasa disebut dengan $\mathrm{RnD}$, yang bertujuan memberikan contoh nyata bagaimana cara mengajar dan menanamkan kesiapsiagaan bencana gempabumi pada masyarakat sekolah secara sederhana dan menyenangkan dengan model pembelajaran kesiapsiagaan bencana. Hasil penelitian berupa desain model pembelajaran kesiapsiagaan bencana gempabumi dan struktur pembelajaran yang merupakan penerapan pendekatan saintifik pada kesiapsiagaan bencana. Penelitian ini berdasarkan pengembangan dan pengalaman tim peneliti dalam mengajar dan melakukan penelitian pada kepala sekolah, guru dan peserta didik di SD Negeri 6 Mataram. SD Negeri 6 Mataram merupakan pilot project dari penelitian ini dan akan diterapkan pada sekolah-sekolah lain di daerah kota, pesisir dan pegunungan di pulau Lombok. Respon kepala sekolah dan bapak ibu guru terhadap model pembelajaran kesiapsigaan ini sangat positif, dimana 95\% menyatakan sangat tertarik dan hanya $5 \%$ yang menyatakan tertarik. Peserta didik sangat antusias dan terlibat aktif selama proses pembelajaran dan mereka merasakan manfaat yang berarti dari pembelajaran kesiapsigaan ini. Hal ini mengindikasikan bahwa model pembelajaran kesiapsigaan ini dapat menjadi acuan dalam menanamkan kesiapsigaan bencana pada masyarakat sekolah.
\end{abstract}

Kata Kunci : model pembelajaran kesiapsiagaan gempabumi; sekolah dasar; pulau Lombok; bencana

\section{ABSTRACT}

Teaching is every teacher's daily job. Despite this, though, teaching in the way that students learn is not an easy thing to do. This research is a Research and Development-also known as RnD—study, aimed to give a real life example of how a teacher can teach and embed the awareness about natural disaster in an uncomplicated and fun way, by using disaster mitigation model of teaching. The study results in one design of disaster mitigation model of teaching and a teaching structure implementing scientific approach on disaster mitigation. This research is based on the development and real life experience of the researcher team in teaching and doing observation and research on the headmaster, teachers, and students of SD Negeri 6 Mataram. SD Negeri 6 Mataram is the pilot project of this study, which in return will be implemented in other schools in the urban, coastal area, as well as mountanious area in Lombok Island. The result shows that the headmaster and the teachers' response towards disaster mitigation model of teaching had been really positive, with only $5 \%$ of the teachers claims that they are interested, whilst the other $95 \%$ claims that the study is extremely interesting for them. The students were very enthusiastic and active during the learning process. In addition, the claim to have meaningful benefit from this mitigation learning. This thus indicated that this disaster model of teaching and learning can be used as a guide or reference in embedding the awareness for natural disaster among school community.

Keywords: model of learning; disaster awareness; primary school; earthquake

\section{PENDAHULUAN}

Lombok sebagai salah satu pulau di wilayah Indonesia yang sangat rentan terjadinya gempabumi. Baru baru ini di tahun 2018 antara bulan Juli sampai Agustus pulau Lombok diguncang 4 kali gempa bumi berkekuatan besar, yaitu 29 Juli 2018 kekuatan 6,4 SR, 5 Agustus 2018 kekuatan 7 SR, 9 Agustus 2018 kekuatan 6,2 SR dan 19 Agustus 2018 berkekuatan 7 SR ditambah dengan rentetan gempa susulan yang mencapai 2500 kali. Hal ini terdampak luar biasa pada 
masyarakat di pulau Lombok terutama di daerah pantai, pegunungan dan perkotaan. Ditandai dengan hancurnya bangunan dan infrastruktur di daerah yang terdampak dan yang sangat memilukan adalah terdapatnya korban ratusan korban jiwa pada rentetan gempa Lombok ini. Hasil observasi dan studi pendahuluan menunjukkan bahwa kesiapsiagaan masyarakat terhadap gempa bumi sangat kurang. Gempa bumi merupakan bencana alam yang tidak dapat diprediksi kapan terjadinya (Syahrial, 2019). Gempa bumi bisa terjadi tiba-tiba seperti saat bekerja, tidur, bermain, dan bahkan juga saat belajar di sekolah (Disaptono, 2005). Peserta didik adalah kelompok yang paling rentan menjadi korban gempa bumi demikian juga guru dan perangkat sekolah lainnya. Maka dari itu mereka sangat perlu dibekali konsep proses terjadinya gempa bumi, dampak gempabumi dan langkah-langkah penyelamatan diri dari gempa bumi terutama bila gempabumi terjadi saat peserta didik sedang belajar di kelas. Mengajarkan sesuatu yang baru kepada anakanak tentu membutuhkan metode yang tepat, efektif dan menyenangkan (Djamarah, 2005). Artikel ini memaparkan contoh nyata pembelajaran kesiapsiagaan gempabumi di sekolah. Model pembelajaran kesiapsiagaan gempabumi ini, dikembangkan dengan menerapkan pendekatan saintifik. Pendekatan saintifik menggunakan pembelajaran penemuan (Discovery Learning) (Irawan, 1997). Discovery Learning merupakan suatu model pembelajaran yang melibatkan secara maksimal seluruh kemampuan peserta didik untuk mencari dan menemukan sesuatu benda, manusia atau peristiwa secara sistematis, kritis, logis, analitis sehingga peserta didik dapat merumuskan sendiri penemuannya dengan penuh percaya diri (Syahrial, 2011). Selama proses pembelajaran, guru semestinya membantu siswa untuk aktif dalam mencari konsep, prinsip dan fakta bagi dirinya sendiri, bukan hanya memberikan ceramah dan mengendalikan kelas (teachers oriented), dengan demikian siswa akan mampu untuk membangun pengetahuannya sendiri (Muryani, 2015). Kesiapsigaan bencana pada peserta didik, guru dan kepala sekolah akan muncul dari proses pembelajaran kesiapsigaan yang dilaksanakan. Tanpa ada proses ini mustahil kesiapsiagaan bencana akan terpatri pada mereka sehingga tujuan utama untuk mencapai masyarakat sadar bencana akan sulit (Klinger, 1997). Keterampilan proses sains sebenarnya menjadi dasar pendekatan saintifik di kurikulum 2013. Salah satu kegiatan yang dapat diambil guru adalah melakukan praktek (Ramdhani, 2005). Praktek, peserta didik dapat memperoleh pengalaman langsung mengenai kebencanaan dan kesiapsiagaan. Peserta didik akan lebih mudah mengingat suatu konsep bencana jika ia melihat langsung. Peserta didik bahkan tidak hanya sekedar mengingat tetapi mengerti suatu konsep bencana jika ia mengalami sendiri. Melalui praktek, siswa dapat menemukan masalah sekaligus mencari jawaban atas masalah yang ditemukan. Masalah yang muncul melalui praktek merupakan sumber ransangan yang sangat potensial untuk belajar lebih banyak. Dengan praktek akan terjadi proses belajar yang punya kandungan ilmiah yang berbobot (Suprapto, 2002). Masalah akan dipecahkan sendiri lewat praktek tanpa perlu ceramah teoritis dari gurunya. Melalui praktek, siswa dapat juga dilatih untuk menggunakan metode-metode ilmiah sederhana yang sahih seperti halnya seorang ilmuwan (Hamidah, 2018). Tulisan ini didasarkan pada hasil penelitian, pengalaman dan pengamatan pembelajaran kebencanaan di kelas menggunakan pendekatan saintifik dengan praktek (Ivers, 2002). Permasalahan yang menarik adalah:

(1) Bagaimana mengajarkan kesiapsiagaan gempabumi pada peserta didik di sekolah dasar?

(2) Bagaimana struktur pembelajaran kesiapsiagaan gempabumi yang berorientasi pada peserta didik?

(3) Bagaimana respon peserta didik terhadap pembelajaran kesiapsiagaan gempabumi di sekolah dasar?

\section{METODE PENELITIAN}

Model pembelajaran kesiapsiagaan gempabumi dan struktur pembelajaran yang ditemukan merupakan hasil penelitian dan pengembangan (research and development) yang dilakukan tim peneliti. Penelitian ini sebenarnya telah dilakukan secara kontinu lebih awal selama tim peneliti bergabung di proyek peningkatan kesiapsiagaan bencana 
bagi peserta didik di sekolah dasar kerjasama Indonesia Jerman yang disebut DAPS (Disaster Awareness in Primary School) dari tahun 2007 sampai dengan 2013. Hasil penerapan model yang telah dirancang peneliti di berbagai tempat ini di evaluasi dan direfleksikan pada penerapan berikutnya, sehingga didapatkan model pembelajaran kesiapsiagaan gempabumi pada saat ini (Ivers, 2002). Penelitian ini adalah penelitian pengembangan yang dilakukan 6 tahap, yaitu: (1) Reseach and information collecting, (2) Planning, (3) Develop preliminary form of product, (4) Prelimary field testing, (5) Main Product revision, (6) Operational field testing and final product revision (Sugiyono,2013). Pada tahap (1) dilakukan penggalian informasi tentang kesiapsiagaan bencana gempabumi kepada peserta didik dan guru. Penggalian informasi ini didapat melalui angket peserta didik dan guru. Data studi awal dan literatur tentang kesiapsiagaan bencana tsunami juga menjadi informasi awal dalam mengembangkan model pembelajaran kesiapsiagaan bencana gempabumi. Tahap ke (2) berdasarkan studi awal dan literatur yang sudah dianalisis, tim mendefenisikan keterampilan melalui perangkat pembelajaran yang dikembangkan dengan merumuskan terlebih dahulu kemampuan dan tujuan khusus yang ingin dicapai. Setelah itu baru disusun draft awal rencana pelaksanaan pembelajaran kesiapsiagaan gempabumi yang akan menjadi cikal bakal perumusan struktur pembelajaran kesiapsiagaan bencana gempabumi. Tahap (3) bentuk permulaan buku kesiapsiagaan telah tersusun dan telah divalidasi kelayakannya oleh para ahli. Pada tahap ini pula tim melakukan persiapan dokumen pendukung dan alat-alat pendukung untuk tahap implementasi. Tahap (4) tim melakukan implementasi pembelajaran kesiapsiagaan gempabumi di kelas dengan pedoman rencana pelaksanaan pembelajaran yang sudah dibuat. Pada tahap ini diperoleh data observasi pembelajaran kesiapsiagaan gempabumi, data evaluasi dan refleksi dari tim dan guru untuk implementasi berikutnya. Tahap (5) berdasarkan observasi, evaluasi yang dilakukan oleh tim dan guru serta refleksi yang sudah di implementasikan berulang sesuai indikator yang telah ditetapkan, tim merumuskan struktur pembelajaran kesiapsiagaan gempabumi di sekolah dasar. Tahap (6) produk struktur pembelajaran kesiapsiagaan gempabumi telah dihasilkan. Jika memungkinkan bisa dilakukan pengujian ulang untuk memantapkannya. Struktur pembelajaran ini, yang akan menjadi pondasi bagi pengembangan model-model pembelajaran kesiapsiagaan gempabumi dan bisa juga menjadi dasar bagi pengembangan model pembelajaran mitigasi bencana alam.

\section{HASIL DAN PEMBAHASAN}

Pendekatan saintifik merekomendasikan 3 pembelajaran, yaitu (1) Discovery Learning, (2) Problem Based Learning dan (3) Project Based Learning. Berbeda dengan metode ceramah, fokus utama dari metode belajar menemukan adalah kegiatan peserta didik secara mandiri (Huda, 2013). Memang materi dipilih dan disiapkan oleh guru, tetapi para siswa yang secara mandiri membahas suatu masalah tertentu atau guru melemparkan suatu pertanyaan tertentu di awal pembelajaran. Diskusi maupun proses kegiatan sebagian besar ditentukan sendiri oleh siswa, baik selama pelajaran di kelas maupun di dalam kelompok. Metode ini mempunyai beberapa keunggulan, diantaranya adalah:

a) pengembangan kemandirian dan kegiatan mandiri peserta didik

b) stimulasi kemampuan merencanakan, mengorganisasi dan melaksanakan kegiatan

c) pengembangan tanggung jawab terhadap suatu kegiatan, dan

d) pengenalan metode-metode kerja dan berpikir dalam bidang penelitian.

Model discovery learning berpengaruh positif terhadap hasil belajar peserta didik (Subrata, 2001). Salah satu keberhasilan utama dari praktek dan teori pengajaran abad ini adalah bahwa peserta didik dianggap sebagai mitra yang bertindak dan berpikir, dan bukan lagi diharapkan untuk menguasai dan menghafal pengetahuan yang tidak ia pahami atau tidak diterangkan secara objektif. Metode belajar menemukan memungkinkan siswa untuk mengalami sendiri bagaimana caranya menemukan keterkaitan-keterkaitan baru dan bagaimana caranya meraih pengetahuan melalui kegiatan mandiri. 
Tabel 1:Struktur Pengajaran Pemecahan Masalah

\begin{tabular}{|l|l|}
\hline $\begin{array}{l}\text { Langkah } \\
\text { Pengajaran }\end{array}$ & Tujuan Langkah Pengajaran \\
\hline Motivasi & $\begin{array}{l}\text { Membangkitkan rasa tertarik } \\
\text { dan } \\
\text { keingintahuan } \\
\text { terhadap materi pelajaran } \\
\text { yang akan diajarkan }\end{array}$ \\
\hline $\begin{array}{l}\text { Penjabaran } \\
\text { masalah }\end{array}$ & $\begin{array}{l}\text { Merumuskan } \\
\text { pertanyaan ilmiah }\end{array}$ \\
\hline $\begin{array}{l}\text { Penyusunan } \\
\text { opini }\end{array}$ & Perumusan hipotesis \\
\hline $\begin{array}{l}\text { Perencanaan } \\
\text { dan onstruksi }\end{array}$ & $\begin{array}{l}\text { Persiapan peralatan praktek } \\
\text { yang } \\
\text { akan digunakan }\end{array}$ \\
\hline Praktek & $\begin{array}{l}\text { Perwujudan suatu reaksi } \\
\text { alam }\end{array}$ \\
\hline Kesimpulan & $\begin{array}{l}\text { Kesimpulan suatu prosedur } \\
\text { pemecahan } \\
\text { masalah }\end{array}$ \\
\hline Abstraksi & Hasil ilmiah yang sah \\
\hline $\begin{array}{l}\text { Konsolidasi } \\
\text { pengetahuan } \\
\text { melalui } \\
\text { aplikasi dan } \\
\text { praktek }\end{array}$ & $\begin{array}{l}\text { Pengetahuan komprehensif } \\
\text { atas suatu alam } \\
\text { gejala } \\
\text { pengintegrasian } \\
\text { hasil pendidikan }\end{array}$ \\
\hline
\end{tabular}

(Klinger, 1997)

Model pembelajaran berbasis masalah (Problem Based Learning) adalah penyelesaian masalah terkait materi pembelajaran, bukan bagaimana guru menyampaikan materi pembelajaran. Model pembelajaran berbasis masalah dengan metode eksperimen menyediakan pengalaman autentik yang mendorong peserta didik untuk belajar aktif (Ibrahim, 2000). Model pembelajaran kesiapsiagaan dikembangkan berdasarkan pendekatan-pendekatan yang diuraikan sebelumnya. Terdapat 3 tahapan pokok pada pembelajaran kesiapsigaan bencana ini, yaitu: (1) kegiatan awal, (2) kegiatan inti, dan (3) kegiatan pemantapan. Masing-masing kegiatan pada tahapan pokok ini mempunyai tujuan tertentu.

\section{Kegiatan Awal}

Kegiatan awal pada pembelajaran kesiapsiagaan gempabumi bertujuan memotivasi peserta didik sehingga peserta didik tertarik, ingin mengikuti materi pembelajaran kesiapsiagaan gempabumi yang akan dilakukan. Hal ini sangat penting dilakukan untuk memunculkan kerinduan peserta didik belajar terutama tentang kesiapsigaan bencana. Ada banyak alternatif kegiatan yang dapat dilakukan guru untuk memotivasi peserta didik. Alternatif kegiatan yang dapat dipilih oleh guru pada kegiatan awal adalah: (1) demo sesuatu yang dibawa/guru, (2) pemutaran video, (3) bercerita/kejadian, (4) bernyanyi (sesuai dengan materi kebencanaan yang diberikan), (5) Review/melanjutkan pelajaran terdahulu yang tidak lengkap, (6) mengamati/membahas penerapan teknis di lingkungan, (7) menyajikan fenomena, (8) menggali pengetahuan awal peserta didik, dan (9) bisa juga menampilkan poster/gambar tentang bencana. Intinya dari kegiatan awal yang dirancang guru ini, peserta didik mampu secara mandiri menemukan permasalahan pembelajaran yang akan diajarkan. Bila masalah itu ditemukan sendiri oleh peserta didik diharapkan peserta didik akan tertarik dan termotivasi untuk melaksanakan pembelajaran selanjutnya. Sebagai contoh, untuk membuat peserta didik tertarik guru mempersiapkan pemutaran video tentang proses terjadinya gempabumi dan dampak yang ditimbulkannya.Video yang diputar diambil dari link

https://m.facebook.com/story.php?story fbid=1 $231891816952572 \& i d=190650671076697$.

Setelah pemutaran video guru mengajukan beberapa pertanyaan yang mampu menggiring peserta didik pada permasalahan pembelajaran. Contoh pertanyaan yang diajukan guru adalah bencana alam yang sering terjadi di Indonesia adalah gempabumi, kata gempabumi tentu sudah tidak asing bagi kalian. Apakah yang dapat kalian rasakan atau lihat jika terjadi gempabumi?

Kita merasakan getaran dan goyangan, benda yang tadinya tidak bergerak menjadi bergerak. Apakah benda benda itu bergerak sendiri?

Pada waktu gempa terjadi, kalian berada dimana? Sedang apa? Dan dapatkah gempa terjadi di saat kalian belajar di kelas?

Guru menjelaskan dengan gambar Lombok merupakan pulau yang sangat rentan dengan gempa. Pulau Lombok dikelilingi oleh beberapa sumber gempa, yaitu diantaranya Zona Back Arc Thrust di wilayah Utara, Megathrust di Selatan, dan sistem sesar geser di sisi Barat dan Timurnya. 


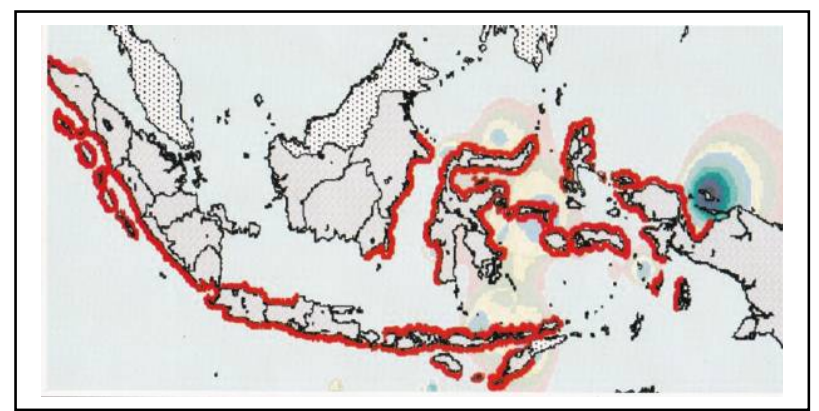

Gambar 1. Lempeng Áktif di Indonesia.

Diharapkan dari pertanyaan-pertanyaan dan penjelasan ini, peserta didik akan terpancing untuk bertanya:

Apakah dampak yang ditimbulkan oleh gempabumi?

Bagaimana langkah-langkah penyelamatan diri bila terjadi gempa saat kita belajar di kelas?

\section{Kegiatan Inti}

Permasalahan yang muncul diakhir kegiatan awal, mengindikasikan seorang guru mulai melangkah pada kegiatan inti. Permasalahan itu jangan dijawab oleh guru, tapi cukup ditampung saja, beri penghargaan lebih baik. Guru hanya mengarahkan peserta didik, untuk menjawab permasalahan ini, kita lakukan kegiatan berikut. Pada kegiatan inti pada pembelajaran kesiapsiagaan gempabumi, yang perlu diperhatikan adalah sebelum terjadi bencana, saat terjadi bencana, proses penyelamatan diri dari bencana, saat sampai di daerah aman, dan saat pertolongan pertama pada korban. Alternatif kegiatan yang dapat dipilih oleh guru adalah: (1) melaksanakan praktek, (2) permainan/simulasi, klasifikasi/pengelompokan, (4) Periksa peta evakuasi, (5) periksa alat teknis pertolongan pertama pada korban, dan (6) menganalisis gambar/foto. Pada pembelajaran kesiapsiagaan gempa bumi di SD Negeri 6 Mataram, dipilih alternatif kegiatan menganalisis gambar/foto. Awal kegiatan inti guru membagikan berbagai macam foto gempabumi kepada siswa. Foto-foto ini berisi pesan tentang (1) dampak gempabumi dan, (2) langkah-langkah penyelamatan diri peserta didik dan guru bila terjadi gempabumi saat belajar di kelas. Peserta didik diminta untuk memahami foto-foto itu, dan menentukan pesan yang dimaksud. Foto foto itu adalah:

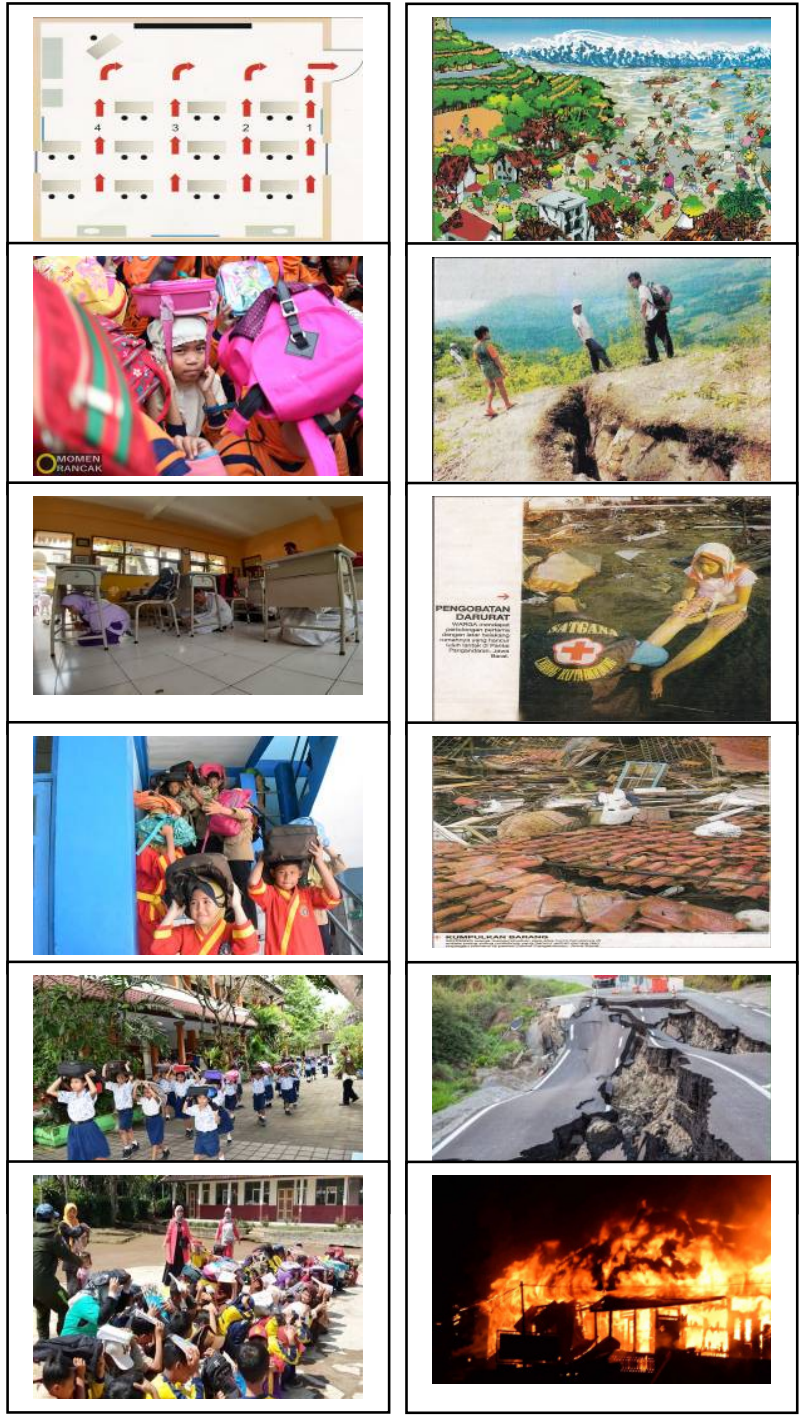

Gambar 2. Langkah-Langkah Penyelamatan Diri dan Dampak Gempabumi.

Kemudian guru meminta beberapa kelompok mempresentasikan hasil diskusi kelompoknya. Pada proses ini, peserta didik diharapkan berpartisipasi aktif dan melakukan pengamatan sebanyak mungkin. Berdasarkan penjelasan oleh siswa (tebak-duga-diskusi) dan landasan pemikiran diharapkan peserta didik mampu menarik kesimpulan sendiri. Setelah kesimpulan didapat oleh peserta didik, permasalahan yang muncul diawal kegiatan inti akan terjawab sendiri. Peserta didik yang akan merasakan sendiri jawaban-jawaban mereka diawal kegiatan inti tadi benar atau salah. Jadi tidak guru yang membenarkan atau menyalahkan. Proses ini yang membuat pembelajaran kesiapsigaan bencana menjadi menyenangkan, membuat penasaran dan inovatif. Untuk lebih memantapkan konsep yang didapatkan guru bersama peserta didik menyanyikan lagu langkah-langkah penyelamatan diri dari gempabumi bila terjadi 
saat belajar di kelas. Lagu tersebut terdapat di youtube dengan https://www.youtube.com/watch?v=cQOuKpzL gLE.

Lirik lagunya adalah:

Kalau ada gempa

Lindungi Kepala

Kalau ada gempa

Jauhilah

kaca

Kalau ada gempa

Bersiaplah antri

Berbaris keluar

Kumpul di lapangan

Irama lagu adalah pelangi-pelangi

AT Mahmud

\section{Kegiatan Pemantapan}

Pada kegiatan pemantapan guru melakukan simulasi langkah-langkah penyelamatan diri dari kelas bila terjadi gempabumi. Proses simulasi dapat dilihat pada video kegiatan pembelajaran kesiapsiagaan gempabumi di SD Negeri 6 Mataram. Video sudah tim peneliti share di youtube: https://www.youtube.com/watch?v=TIKA0ga2v J8\&t=1s. Untuk mengakhiri pembelajaran kesiapsiagaan gempabumi ini guru kembali mengajak peserta didik bersama sama menyanyikan lagu siaga bencana, dengan lirik :

Tinggal di Indonesia

Bersama banyak gempa

Tsunami juga ada

Di desa dan di kota

Ayo kita siaga

Agar slamat semua

Lekas-lekas pahami tandanya

Kalau gempa melanda

Lindungilah kepala

jauhi dari kaca

Masuklah kolong meja

Saat gempa mereda

Lari ke tempat terbuka

Jangan lupa bawa tas siaga

Jika gempa terasa

Tiga puluh detik lamanya

Kuat lemah tak beda

Tsunami bisa ada

Ajak sluruh keluarga

Ke tempat aman sementara

Tiga puluh menit waktu tersisa
Ayo berlari saja

Tinggalkan mobil semua

Ke tempat yang kita bisa

Tiga puluh meter tingginya

Jika kita di sana

Tsunami tak berdaya

Semoga selamat sejahtera semua

Irama lagu adalah : becak karangan Ibu Sud

Pada kegiatan pemantapan ada beberapa hal yang harus dibahas oleh guru, yaitu : (1) penerapan (berhubungan dengan lingkungan peserta didik), (2) menjawab pertanyaan, (3) membuat ringkasan, dan (4) memberikan pekerjaan rumah. Bila kita kaitkan alur pembelajaran ini dengan pendekatan saintifik, sangat sesuai dengan tahapan-tahapannya. Ada 6 tahapan pendekatan saintifik, yaitu: (1) Mengamati, (2) Menanya, (3) Mengumpulkan Informasi, (4) Mengasosiasi, (5) Menyimpulkan, , (6) Mengkomunikasikan. Berdasarkan hasil ini, tim peneliti menemukan struktur pembelajaran kesiapsigaan bencana adalah sebagai berikut:

Tabel 2 memperlihatkan tahapantahapan pembelajaran kesiapsiagaan bencana yang digambarkan pada struktur pembelajaran. Pada bagian alternatif kegiatan yang dapat dipilih oleh guru mengindikasikan kepada guru bahwa itu adalah kegiatan yang dapat di pilih pada masing masing tahap pembelajaran. Struktur ini tidak membatasi kreatitifitas guru dalam mengajar tapi diharapkan mampu memancing motivasi, kreatifitas dan inovasi guru dalam mengajar kesiapsiagaan bencana di sekolah. Struktur pembelajaran ini, berlaku untuk semua model pembelajaran kesiapsiagaan bencana alam seperti gempabumi, tsunami, tanah longsor, banjir, gunung berapi, kekeringan dan angin topan. Guru sebagai ujung tombak bagi peserta didik di sekolah seharusnya sangat memahami kesiapsiagaan terhadap bencana. Aspek kesiapsiagaan guru dalam menghadapi bencana termasuk dalam harus baik. Indikator baiknya karena sebagian besar mereka mengalami bencana gempa bumi yang terjadi pada bulan Juli sampai dengan Desember 2018 sehingga lebih mempunyai kesiapsiagaan yang tepat dalam mengahadapi bencana gempa bumi. Pengalaman mereka ini kemudian diceritakan kembali kepada saudara dan keturunannya sehingga mereka juga dapat mengetahui dan ikut merasakan pengalaman menghadapi bencana gempa bumi yang terjadi. Pengalaman mengalami bencana dapat 
membentuk kesiapsiagaan yang tepat, dan pernyataan bahwa pendidikan dan pengalaman merupakan faktor yang dapat mempengaruhi pengetahuan.

Tabel 2. Struktur Pembelajaran Kesiapsiagaan Bencana Rekomendasi Penelitian

\begin{tabular}{|c|c|c|}
\hline Tahap Pokok & Tahap Pembelajaran & $\begin{array}{l}\text { Alternatif Kegiatan yang dapat } \\
\text { dipilih oleh Guru }\end{array}$ \\
\hline \multirow[t]{2}{*}{ 1. Kegiatan Awal } & Pendahuluan & $\begin{array}{l}\text { (1) demo sesuatu yang dibawa guru } \\
\text { (2) pemutaran video } \\
\text { (3) bercerita/kejadian } \\
\text { (4) bernyanyi (berhubungan dengan } \\
\text { materi kebencanaan yang } \\
\text { diajarkan) } \\
\text { (5) review/melanjutkan pelajaran } \\
\text { terdahulu yang belum lengkap } \\
\text { (6) mengamati/membahas penerapan } \\
\text { teknis dalam lingkungan } \\
\text { (7) menyajikan fenomena }\end{array}$ \\
\hline & (8) Pengetahuan awal siswa & $\begin{array}{l}\text { mengumpulkan dan mendiskusi- } \\
\text { kan }\end{array}$ \\
\hline \multirow[t]{4}{*}{ 2. Kegiatan Inti } & $\begin{array}{l}\text { Perumusan pertanyaan/ } \\
\text { permasalahan tentang topik } \\
\text { kesiapsigaan bencana }\end{array}$ & $\begin{array}{l}\text { merumuskan pertanyaan atau } \\
\text { permasalahan tentang topik } \\
\text { kesiapsigaan bencana }\end{array}$ \\
\hline & $\begin{array}{l}\text { Kegiatan } \\
\text { (a) sebelum terjadi bencana } \\
\text { (b) saat terjadi bencana } \\
\text { (c) saat penyelamatan diri } \\
\text { (d) saat sampai daerah aman } \\
\text { (e) saat pertolongan korban }\end{array}$ & $\begin{array}{l}\text { (1) melaksanakan praktek } \\
\text { (2) permainan/simulasi } \\
\text { (3) klasifikasi/pengelompokkan } \\
\text { (4) periksa peta evakuasi } \\
\text { (5) periksa alat teknis pertolongan } \\
\text { pertama pada korban }\end{array}$ \\
\hline & (6) Pengamatan & $\begin{array}{l}\text { Melakukan pengamatan sebanyak } \\
\text { mungkin }\end{array}$ \\
\hline & $\begin{array}{r}\text { (7) Jawaban pertanyaan } \\
\text { pemecahan masalah }\end{array}$ & $\begin{array}{l}\text { - penjelasan oleh siswa (tebak- } \\
\text { duga-diskusi) } \\
\text { - landasan pemikiran } \\
\text { - } \text { perumusan kesimpulan }\end{array}$ \\
\hline \multicolumn{3}{|c|}{ Penjelasan oleh Guru (bila diperlukan) } \\
\hline $\begin{array}{l}\text { 3. Kegiatan } \\
\text { Pemantapan }\end{array}$ & & $\begin{array}{l}\text { (1) penerapan (sangat baik bila } \\
\text { berhubungan dengan lingkungan } \\
\text { peserta didik) } \\
\text { (2) menjawab pertanyaan } \\
\text { (3) membuat ringkasan } \\
\text { (4) pekerjaan rumah }\end{array}$ \\
\hline
\end{tabular}

Aspek ini berisi pertanyaan tentang apa yang dilakukan peserta didik sebelum, saat akan ada tanda-tanda akan terjadi bencana, saat menyelamatkan diri menuju daerah yang aman dan saat yang dilakukan sampai pada daerah yang aman. Pengetahuan, sikap dan keterampilan tentang ini harus terbentuk pada diri peserta didik sehingga timbul tingkat kesadaran terhadap bencana. Hal ini sesuai dengan pernyataan bahwa pengetahuan dan kesiapsiagaan dalam menghadapi bencana dibutuhkan dalam mitigasi komunitas terhadap bencana. Pengetahuan dan sikap mengenai kesiapsiagaan menghadapi bencana adalah kemampuan yang harus dimiliki oleh setiap individu sebagai wujud dari kesiapsiagaan dalam menghadapi bencana. Perubahan tingkah laku peserta didik berkat adanya pengalaman yang diberikan melalui latihan untuk dapat menyelesaikan masalah yang dihadapi.

\section{SIMPULAN DAN SARAN}

Penerapan

pendekatan saintifik/discovery learning pada model pembelajaran kesiapsiagaan gempabumi sangat cocok dalam pembelajaran kebencanaan. Terbukti bahwa pembelajaran ini membuat para siswa lebih memahami konsep dampak gempabumi dan langkah-langkah penyelamatan diri yang dipelajarinya, lebih antusias dan terlibat aktif dalam mengikuti pembelajaran tersebut. Demikian juga pada gurunya, metode ini menuntut banyak kemampuan yang harus dimiliki oleh seorang guru, misalnya guru harus menguasai materi, terbiasa berpikir logis seperti seorang ilmuwan, sikap mental yang terbuka (demokratis), cepat tanggap membaca pikiran orang lain, dan ingin selalu berkembang. Anggapan guru bahwa pendekatan saintifik membatasi kreatifitas guru menjadi terpatahkan karena ternyata pendekatan saintifik memberikan kewenangan lebih buat guru dalam mengoptimalkan kreatifitas dan inovasinya.

\section{UCAPAN TERIMA KASIH}

Penelitian ini terselenggara berkat rahmat dari Allah SWT dan bantuan dari berbagai pihak, terutama dari Lembaga Penelitian dan Pengabdian kepada Masyarakat Universitas Mataram dan SD Negeri 6 Mataram. Bersama ini kami tim peneliti mengucapkan terima kasih atas segala bantuan dan kerjasamanya

\section{DAFTAR RUJUKAN}

Diposaptono S. (2005). Tsunami Mitigation Technology. Jakarta: Republic of Indonesia Maritime and Fisheries Agency Tsunami Mitigation Training Material.

Djamarah. (2005). Teachers and Students in Educative Interaction, A Psychological Theoretical Approach. Jakarta: Rineka Cipta.

Huda, M. (2013). Teaching and Learning Model Models of Methodical and Pragmatic Issues. Yogyakarta: Pustaka Pelajar.

Hamidah, Gunawan, \& Muhammad Taufik. (2018). Effect of Media Assisted Discovery Learning Model on Physics Learning Outcomes of Class XI Students of SMA N 1 Kediri Academic 
Year 2017/2018. Jurnal Pendidikan Fisika dan Teknologi. 4(1). 78-86.

Irawan P. (1997). Learning Theory. PAU-PPAI. Jakarta: Universitas Terbuka.

Ibrahim. Muslimin. (2000). Problem Based Learning. Surabaya: University Press.

Ivers, Baron. (2002). Multimedia Projects in Education Designing Producing and Assesing. New York: John Willey \& Sons.

Klinger, Walter. (1997). Survey of Teaching Methods in Natural Sciences Erziehungswiss. Fakultat der Universtat: Erlangen-Nurnbe.

Muryani, A.D., \& Rochmawati. (2016). "Differences in Student Learning Outcomes Using Assisted Discovery Learning Learning Models and Without Assistance to Student Worksheets". Jurnal Pendidikan Ekonomi. 1(1). 7-13.

Ramdhani A. (2005). Optimization of Physics Learning with the Use of Science Kits at SMP N 6 Mataram. Mataram: Press Unram.

Subrata. (2001). Efforts to Improve the Quality of Learning Outcomes of Elementary Students through Science Learning with Process Skills. Singaraja : LPPM STKIP Singaraja.

Sugiyono. (2013). Qualitative Quantitative Research Methods and $R$ \& $D$. Bandung: Alfabeta.

Suprapto S. (2002). Flood Disaster, Material for Disaster Power Training. Yogyakarta : PSBA UGM.

Syahrial, A. Kosim. Gunada. (2019). Tsunami. Gunung Sari West Lombok : Arga Puji

Syahrial, A. (2011). Study of the Use of elementry school Science Kits in Mataram, Mataram : Lembaga Penelitian Universitas Mataram 